\title{
Stanisław Brzozowski and fascism
}

\author{
Maciej Urbanowski
}

Published online: 14 October 2011

(C) The Author(s) 2011. This article is published with open access at Springerlink.com

\begin{abstract}
In this article, Brzozowski's much discussed connections with fascism are reconsidered in the context of interpretations of fascism by Sternhell and Gentile. At the end of his life, Brzozowski tried to reconcile socialism and nationalism. He criticized orthodox Marxism and liberal democracy, underlined the political and cultural importance of the nation, praised irrationalism, strength, imperialism, heroism, asceticism, the labourer and the soldier as ideal attitudes with regard to the world. He wanted to turn Poland into a modern nation, but feared some consequences of modernity. Brzozowski's ambivalent attitude towards modernity precludes finding an adequate description for them, in particular in the Polish and Central European context, although his concepts were similar to those of some of his contemporaries from France or Italy, such as Georges Sorel or the "La Voce" group, as well as "antimoderns" as described by Antoine Compagnon. At present labels such as "fascism" or even "proto-fascism" seem to be too ambiguous to grasp the originality of Brzozowski's thinking. The Polish thinker's case suggests a reconsideration of Sternhell's thesis that Eastern-European Marxism remained loyal to the Heglian, rationalist, and materialist essence of Marxism.
\end{abstract}

Keywords Brzozowski $\cdot$ Ideology $\cdot$ Fascism $\cdot$ Modernity

He was dreaming about cold, ruthless, solitary and vulture-like thought for his own homeland. Poles would become invaders because of their hard wisdom.

They would drive pales into the bottoms of Russian rivers and lakes.

He didn't doubt there was only the solitary human will, the only law in a world of granite - bright pale steel.

(Brzozowski 1975, 451)

M. Urbanowski ( $\bowtie)$

Department of Polish Literature, Jagiellonian University, Gołębia 16, 31-007 Kraków, Poland

e-mail: maciej.urbanowski@uj.edu 
A new edition of Stanisław Brzozowski's books by the leftist periodical Krytyka Polityczna ("Political Critique") enlivened interest in this important but somewhat forgotten writer in the wake of 1989 in Poland. They also served as the occasion to raise some new questions or to come back to subjects which had been touched on in the past. One of these is a controversy about the right to include Brzozowski in the pantheon of leftist writers. The fact that Brzozowski's "come back" was initiated by a leftist group is not very surprising because his books have been used by very different and often antagonistic circles within the Polish intelligentsia. Marian Stępien, in his book about the reception of the author of The Legend of Young Poland in the period 1918-1939, remarked that Brzozowski's ideas were "[...] sometimes a kind of catalyst, sometimes a pretext which facilitated the development of the self-consciousness of different political orientations [...]: from the radical left to the extreme, fascist-like right." (Stępień 1976, 6).

What explains these different readings of Brzozowski? Was it a consequence of simple ignorance on the part of his readers, or a result of a reduction, typical for ideological readings of any outstanding thinker? Or was it the "fault" of Brzozowski himself who changed his positions and ideas and whose language was often very ambiguous?

The Marxist literary critic Andrzej Stawar remarked before the Second World War that: "[...] this national agreement about Brzozowski, when a monarchist, a fascist, and... a communist manage to draw from this single well of truth, is a matter that certainly raises questions." (Stawar 1957, 75-76). Many years later, Krzysztof Pomian still wondered: "[...] how was it possible that in the same set of writings [of Brzozowski] some people managed to discover the most excellent Polish socialist philosopher while others discovered-with enthusiasm or with horror-a Nazi avant la lettre." (Pomian 1974, 45).

But those who studied Brzozowski's ideas have warned as well against seeing him as an advocate of a precise political and cultural ideology or party. In 1933 Bohdan Suchodolski remarked that Brzozowski “... broke loose from any doctrinal frames" and "his thought, distinct and original, is too abstract to be translated into the language of actual reality." (Suchodolski 1933, 275). Brzozowski himself underlined that his books "don't have any determinate content and it would be a waste of time to seek any." (Brzozowski 2007a, 8). In one of his letters to his friends he declared: "I do not acknowledge any banner," "I am not from any party, from any creed.” (Brzozowski 1970a, 235, 237).

In the history of Brzozowski readings it is still puzzling how often he was connected with fascism, usually in order to repudiate his ideas. It is interesting that Brzozowski was most often accused of fascism by leftists. In 1929 Stawar published an essay in a communist cultural newspaper "Dźwignia" ("Lever") in which he warned his comrades against Brzozowski, who "resorts to pseudo-revolutionary forms of 
expression to express fascist propaganda." (Stawar 1957, 117). In 1937 a socialist literary critic and writer Jan Nepomucen Miller, commenting on Brzozowski's remarks about the nation in The Legend of Young Poland, observed that "no modern fascist would be ashamed of such words [about the nation]." (Stępień 1976, 175).

According to Czesław Miłosz, the idea promoted by the communists, that one could easily become nationalist and fascist under Brzozowski's influence, gained prevalence before the Second World War. Miłosz explained that although Brzozowski wasn't nationalist he had "quite profusely" used words like "nation" and "national" which "had appeared on the banners of all fascist groups" (Miłosz 1982, 48-51).

Thus the communist's conviction concerning the fascist character of Brzozowski's ideas not only "effectively frightened leftists away from his writings," but was also the reason why his books were put on the index in Poland after 1945 (ibid. 52). The communists claimed that during the Second World War clandestine rightist periodicals "had shown the real face of Brzozowski-as a precursor of fascism" and that "Brzozowskism was [...] an ideological precursor of Polish fascism." (Sroka 1970, XLI).

But Brzozowski was linked to fascism not only by the communists. For example, the outstanding independent Polish literary essayist Karol Irzykowski observed in 1935 that the career of the author of The Ideas resembled that of his intellectual champion Georges Sorel, who "in his last years blessed Lenin but had raised Mussolini." (Stępień 1976, 70). The admirer of Jacques Maritain and the literary vanguard, Ludwik Fryde, came to the conclusion, after reading The Legend of Young Poland, that "Brzozowski was undoubtedly a precursor of the social ideology of fascism." (Fryde 1966, 173). Miłosz made very similar observations in 1943: "it was easy to squeeze different slogans dear to fascist's hearts out of Brzozowski." (Miłosz 1996, 132). Many years later Miłosz explained that his aversion to Brzozowski was a result of the way in which right-wing writers held the author of The Voices in the Night in esteem (Miłosz 1982).

But which writers? Miłosz referred to Bohdan Suchodolski who published a book about Brzozowski in 1933. Suchodolski was not a fascist and he did not mention Brzozowski's "fascism." At the very most he referred to Brzozowski's "proletarian nationalism" as the penultimate phase of his thinking, succeeded finally by his Catholicism. It remains true, however, that in the 1930s Brzozowski was often quoted by partisans of the radical nationalist Right. The press of the "Obóz Narodowo-Radykalny" (National-Radical Camp) had been transcribing extensive fragments of Brzozowski's writings (Sroka 1970, XXXIX) and he was praised in Prosto $z$ mostu (Plain talking) the most popular nationalist weekly during the Second Republic. But again Brzozowski wasn't praised in these journals as a fascist but as a Polish nationalist or-sporadically—as a "national socialist." (Wasiutyński 2000). It is likewise true that the author of The Ideas was often quoted by the rightwing clandestine press in Nazi occupied Poland. For example, Andrzej Trzebiński, an outstanding young literary critic and novelist as well as editor-in-chief of the literary magazine "Sztuka i Naród" ("Art and Nation"), read Brzozowski as a representative of European "nationalist thought," including among others Barrès, Heidegger, and... Bergson (Trzebiński 1999). 
In fact there were very few writers who read Brzozowski as a fascist with approbation. In 1929 Kazimierz Zakrzewski, in a magazine connected with the Piłsudski camp, Droga ("Way"), wrote that "the ideology propounded by Brzozowski [...] is essentially pre-fascist, though at the same time post-fascist, at once 'before-and-after-Mussolini'." (Stępień 1976, 46). It is significant that Brzozowski's name does not figure in Ferdynand Goetel's Pod znakiem faszyzmu (Under the sign of fascism) from 1939, one of the most important declarations of pro-fascist sympathies in pre-war Poland (Goetel 2006).

The attempts to connect Brzozowski with fascism disappeared after 1956, i.e. following the end of the Stalinist era in Poland. After 1956 Brzozowski's ideas started appearing again and his critics tried to emphasize the leftist character of his ideas, especially his connections with non-orthodox Marxist thinking (Walicki 1977; Mencwel 1990). Even if they did notice some elements in his thinking that were not typical for leftist ideologies, they nevertheless connected him with "modern reactionaries" (Burek 1974, 25) defending him against potential accusations of fascism. For example, Cezary Rowiński remarked that despite his enthusiasm for Sorel Brzozowski made no mention of Sorel's concept of violence and he didn't draw the most radical conclusions from ideas of the author of Reflections on violence (Rowiński 1975). Andrzej Mencwel likewise emphasized differences between Brzozowski's Lebensphilosophie and the "fascist conceptions of Klages or Baeumler" (Mencwel 1976, 403-404).

It needs to be added that most often these attempts to defend Brzozowski referred especially to his last articles and essays, written in Florence where he had moved in 1907 and published in books like The Legend of Young Poland (1909), Ideas (1910), The Voices in the Night (1912), and Diary (1913).

\section{3}

Why is it still worth asking about Brzozowski connections with fascism? After all, the problem seems to be out of date and anachronistic considering that words like "fascist" or "fascism" weren't even in circulation in 1911, the year of Brzozowski's death. Nor did there exist at that time a political phenomenon which could be described as fascism. As we know one had to wait till First World War when it came into being in Italy (Gentile 2004; De Felice 1976). Emilio Gentile also remarked that, although before 1914 there were some ideas of the radical left and radical right (like integral nationalism, syndicalism, futurism) which influenced fascism, they cannot be identified with fascism or even labeled "proto-fascist," because they gave rise to future enemies of fascism (Gentile 2004, 22-24, 416).

"Fascism" seems also to be a very uncomfortable and not very precise category, by far too ambiguous with innumerable definitions. And the term 'fascism' is used in too many contexts, most often pejoratively as a synonym of the Right, counterrevolutionaries, conservatism, authoritarianism, reactionaries, nationalism, racism, imperialism, and many others. Today, in accord with its semantic inflation, fascism is rather a tool serving to denounce, exclude or condemn ideas and writers rather than to explain them (Gentile 2004, 69). 
This was of course often the case with Brzozowski. But today the question of his "fascism" not only requires us to look for these elements in his thought which presage "real fascism" after 1914, it is also a part of the bigger problem of Brzozowski's changing attitudes to modernity. This problem seems also to be obvious and interesting in the light of newer interpretations of fascism by Gentile, Berlin, Nolte, and Sternhell. They understand fascism as a phenomenon deeply rooted in European thought at the turn of the twentieth century. From this point of view, though fascism came into being in Italy it had had predecessors in France and Germany (Nolte 1966; Sternhell 1986; Sternhell et al. 1994; Gentile 2004; Berlin 2004). It seems also to be "characteristic of an era" and it is "a metapolitcal phenomenon" (Nolte 1966); it is characterized by a relatively coherent ideology (Gentile 2004) which cannot be unequivocally identified either with the Right or the Left (Sternhell 1986), and it is typical for modernity.

In the case of Brzozowski, Sternhell's interpretation of fascism seems to be especially interesting. He asserts that fascism was a new kind of synthesis of nationalism and a specific type of socialism. So in the case of France one has to look for its sources not only in the ideology of the Right but more often in that of the Left. And before fascism became a political force it was already a cultural phenomenon; its development would not have been possible without the crisis of liberalism and socialism and without the revolt against the Enlightenment and the French Revolution, so common at the turn of the nineteenth century.

In this sense, fascism was only an extreme consequence of a much broader and much deeper phenomenon. It was a part of the intellectual, scientific, and technological revolution gripping Europe at the beginning of the twentieth century. Sternhell emphasizes that fascism was to be an anti-bourgeois moral revolution. It wanted to create "a new man" who was to be heroic, vigorous, disciplined, capable of sacrifices for the cause of nation, and who believed in the power of human will (Sternhell 1986, 271).

Sternhell maintains that fascism was born in "the ideological laboratory of the Belle Epoque": the fascist synthesis was already clearly formulated about 1910-1912 in magazines like La Lupa in Italy and Cahiers du Cercle Proudhon in France." (ibid., 31). In effect, fascism was a modern phenomenon. Its history is "a history of desire for modernization, for a renewal and adaptation of political systems and theories inherited from antiquity to the requirements and necessities of the modern world." (ibid., 28). In its beginnings fascism was also a rebellion against the atomization of society in the free market economy and against the dehumanization modernization brought into interpersonal relations. But at the same time fascism was an enthusiastic partisan of the benefits resulting from progress, which is why it never proclaimed ideas of a return to a golden age. In Sternhell's opinion, fascism rebelled against modernity to the extent that modernity was identified with the rationalism, optimism, and humanism of the eighteenth century. Thus fascism was neither a reactionary nor an antirevolutionary movement, but rather pretended to be $a$ revolution of another kind. It sought ways of destroying the actual political order and overthrowing its theoretical and moral foundations. At the same time, it sought to preserve the achievements of modern technology. Fascism adopted the economic aspect of liberalism while overthrowing almost entirely its philosophical and ethical 
foundations. Almost entirely, since fascism shared with liberalism its respect for power and the vitality of the free market economy. But according to Sternhell, fascism was closer to Marxism, it was even a kind of Marxism or a consequence thereof: it was an anti-materialistic and antirational revision of Marxism (Sternhell, Sznajder, Asheri). Revisionist Marxism grew up in Western Europe while Austrian, Russian, and Polish Marxists (including Kautsky, Mehring, Bauer, Luxemburg, Radek, and Lenin) remained loyal to the rational, materialist, and Hegelian essence of Marxism. This was an effect of the completely different experiences of East European Marxists and their contemporaries in Western Europe (ibid., 17-19).

To be more precise, a fascism of this kind was born in France at the turn of the nineteenth century, being a combination of an integral nationalism of the radical Right and Marxist revisionism of the radical Left as represented by Georges Sorel, "the intellectual father of fascism." (Sternhell 1986, 9).

It needs to be underscored that this kind of fascism cannot be identified with Nazism, and nor was racism a necessary condition of its existence. Gentile agrees with Sternhell that fascism was a new and modern phenomenon and that its essence consisted in a mixture of revolutionary nationalism, anti-liberalism, anti-materialism, anti-capitalism, and anti-Marxism. Fascism was also hostile towards liberal democracy and Enlightenment principles of freedom and equality. As typical for fascism Gentile emphasized its tragic and activist vision of human life, the will to power, the myth of youth, the concept of militarized politics as a model of life and society, its ethics of subordination of the citizen to the state and the individual to national community. The Italian historian points out that fascism was a project of total, i.e. political, cultural, and anthropological revolution aiming to bring forth a "new man." L'uomo fascista had to be the opposite of the optimistic and rational Cartesian man. He was to be "citizen-soldier," virile, firm, efficient, heroic, capable of sacrifice (Gentile 2004, 354-395).

Gentile stresses in addition that fascism accepted the challenges of modernity. It was not reactionary, i.e. it did not deny modernity. To the contrary, it belonged to it as one of the consequences of a process which began in Europe together with French Revolution (Ibid., 85). Thus fascism cannot be considered a "reactionary modernism," as Jeffrey Herf characterized Nazism (Herf 1986), rather it was a "fascist modernism," with its own vision of modernity opposed to liberal, socialist, and communist visions thereof. In other words, fascism was a project of another modernity (Gentile 2004, 448; Wolin 2004).

Undoubtedly, Stanisław Brzozowski was very interested in many of the ideas of that "other modernity" and its adherents. It is very significant that he enthused about the magazines Leonardo and La Voce published in Florence at the time he lived there. Today both magazines are considered as an important part of the pre-history of Italian fascism. According to Walter Adamson, their main contributors, Giovanni Papini, Giuseppe Prezzolini, and Ardengo Soffici "had unconsciously contributed to laying the cultural foundations of early fascism" (Adamson 1993, 3) while Emilio 
Gentile writes that La Voce was one of the most important sources for the leading founders of fascism, including Mussolini (Gentile 2004, 22).

As a matter of fact Brzozowski was nearly a contemporary of the founders of La Voce. He did not withhold the expression of his utmost appreciation of La Voce which he read regularly. He recommended it to his friends in Poland and even planned to publish some articles published in it. He appreciated La Voce as "an immensely courageous magazine" emphasizing that "between me and La Voce there is almost unanimity" (Brzozowski 1970b, 419). He declared: "Their [La Voce] work makes me envious" (Brzozowski 1990, 30) and he added:

There are but a few periodicals which characterize the spirit of young European intellectual elites as well as Prezzolini's La Voce [...]. This magazine as well as earlier publications of its editor and his collaborator Papini are interesting not only as theory but also as an expression of an instinct making use of theories. [...] Any polemic which would see it as a reactionary tendency would be too facile [ibid. 412].

The list of Brzozowski's intellectual fascinations in the period 1908-1911 includes almost all writers connected with "the birth" of fascism such as Pareto, Nietzsche, Proudhon, Barrès, Maurras, de Maistre, and Georges Sorel (Brzozowski 2007b, 89, 113). The last named was one of the most important philosophical masters for Brzozowski (Wyka 1972).

Like Sorel and the others Brzozowski tried to connect his socialism with a specific kind of nationalism. Rather than repudiate socialism he started to understand it as "a vital process taking place inside working people" (Brzozowski 2001, 107). In 1908 he professed: “[...] I believe in a workers cause, I don't see life without it, but I don't believe in a socialism of parties" (Brzozowski 1970a, 693). A little bit later he confessed:

I feel an organic disgust for the left. The left advocates European socialism [...], which is the most disgusting for me: it is optimistic, altruistic, Beecher Stove-like, whereas I repeat once again: I don't love my fellow creatures, and I regard optimism as an illness to be treated [ibid., 660].

He even acknowledged that "socialism is the most obstinate enemy of the working class" [Brzozowski 1970b, 388] and "what is appreciated as a sign of the progress of socialism is most often only a symptom of the corruption of the bourgeois and feudal social strata" [Brzozowski 1970a, 661]. Brzozowski's attitude towards Marxism was also ambiguous. Under the influence of Sorel he declared: “[...] I don't see Marxism beyond the syndicalist concept of socialism" (Brzozowski 1970a, 307).

Brzozowski's revision of socialism and Marxism was founded on antirational and nationalist premises. He stated that "reason cannot exist if it will not be created by the deep irrationalism of the human essence" (Brzozowski 2007a, 247), that is, "some affinities with a dark blood, with something earlier then blood, bearing in itself forces of every kind and yet formless at the same time" [ibid., 246].

This irrationalism likewise had certain social consequences. According to Brzozowski, society "exists in us as an irrational bond, and this irrational, inexhaustible domain acquires meaning in relation to the question of the future" 
(Brzozowski 2001, 89). Politics, too, appeared to be an irrational domain. As an admirer of Sorel's conception of myth Brzozowski noted that “...political slogans are no more than signs which move instincts" (Brzozowski 1970b, 162).

From this point of view a test of the real meaning and truth of ideas is society or the nation. Brzozowski wrote that "the only truth of our spirit is the victorious body of the nation" (Brzozowski 2001, 445) which is why

The criterion of the forms of spiritual life existing in a nation is the nation's historical prosperity which depends on the level of the biological-economic power the nation has developed. Hence the sole criterion is to strengthen the biological-economic power and productive abilities of Polish society [Brzozowski 1990, 402].

These ideas explain Brzozowski's disdain for cosmopolitism. In The Ideas he emphasized that "a man without a nation is a soul without content, indifferent, dangerous, and harmful" [ibid., 250]. He also stated that "those who hold themselves apart from the nation's word are people who don't live fully and completely, they are incomplete people who are unhappy in the deepest meaning of this word, because they are afflicted by the most horrible catastrophe [...]." [ibid., 270]. In The Voices... Brzozowski added: "there is no a-national international mind, a-national, international art and literature" (Brzozowski 2007a, 174-175).

Brzozowski's praise of the nation went hand in hand with his vision of the Polish nation. He insisted on the necessity of modernizing the Poles, of creating a "modern national consciousness" which "would have to be creation ex nihilo" (Brzozowski 1970a, 337). He imagined Poles to be a victorious nation: vigorous, brave, strong, even dangerous, manifesting a "rapacious will" and the "will to live." He appealed to his countryman: "Fear not. Feel at one with the full surge of Polish energy from King Bolesław Chrobry [Polish king during the Middle Ages] to Aleksander Wielopolski [Polish politician from the nineteenth century]-and [...] disdain weakness" (Brzozowski 1970b, 237).

Brzozowski was a vigorous critic of Polish weaknesses, especially those of the Polish gentry and Polish Catholics. But he didn't jettison the Polish tradition as a whole. In fact, he was seeking for elements of national strength in it. He understood that "the nation is a kind of continuity of will which sustains, raises, and realizes itself" (Brzozowski 1990, 338) and "it is a ground we walk on, a ground built [...] on the will and sacrifices of the dead" [ibid., 234]. Brzozowski preferred a dynamic traditionalism, rejecting a traditionalism of stagnation and inertia.

For these reasons, Brzozowski's apology of strength is worth attending to more closely. In one of his letters he explained: "there is no truth that is blind and abstract, detached from strength. [...] When one stops believing in oneself, in one's courage, drive, and strength, one starts to talk about the truth" (Brzozowski 2001, 199-200). For him strength was "only a brutal form of truth" (Brzozowski 1990, 284) and he cunningly travestied Hegel: "What is not a strength is not real; it is real in as much as it is a strength" (Brzozowski 2001, 435).

Like many other terms in Brzozowski's philosophy, strength was not clearly defined. It was not clearly identified with physical violence being closer instead to a kind of revolutionary violence, though most often it was a synonym of the 
civilizational efficiency of a nation, of its "spirit of conquest" measured by its work and its successes in the struggle to master nature.

Whence too the important place of the category of hardness in Brzozowski's writings, the synonym of all that is bodily, real, inflexible lasting, as opposed to the decadent psyche "which wants to live in a world free of struggle and which believes that such a world is possible and can become an ideal" (Brzozowski 1990, 285). That's why Brzozowski called his readers to "will the hard, realistic struggle" (Brzozowski $2001,435)$ entreating them to "... become a body, a hard reality maintaining itself despite the biological element" [ibid., 438]. He also declared: "we, who accept Western culture and live in it, we accept the hard, militant, rapacious Western life" [ibid., 439]; "I want it known that whatever is not as hard as steel penetrating a tombstone will die, courage notwithstanding" (Brzozowski 1970a, 721).

In this way Brzozowski appealed to Poles to adopt a "policy of national energy" (Brzozowski 2001, 436) explaining that "emotional [...] immolation becomes a historical strength only thanks to biological-economic power" [ibid., 435]. As a model of this attitude he pointed to England and its imperial spirit expressed so well by Kipling:

Let's take Kipling. [...] Here man is free, [here] white man, the source of biological energy which is at the service of his will. The foundation of freedom is the efficient, enterprising human animal, who does not want to give up. Are you embittered? As a matter of fact Kipling displays biological reality [...]. Remember that human psychology as a whole, the entire European world is created by the force of this biological rapaciousness, the conquering rapacious will, the will to live, contributing to this collective soul, which is burning in our dreams [ibid., 437-438].

Brzozowski linked his admiration for imperialism to his critique of parliamentary democracy. He observed that the latter is "a culturally sterile state of mind and soul" (Brzozowski 2001, 313) and that "it produces systems of intellectual fictions which veil reliable, infinitely concrete cultural lives" [ibid., 315]. In other places he observed that "the typical democratic way of feeling, its faith in irresponsibility means that democracy will never give rise to a classical writer, a deeply conscious artist" (Brzozowski 2001, 263), and that "it is a democratic fiction that life can proceed without stern inner or outer discipline" (Brzozowski 1990, 291).

For these reasons Brzozowski admired the labourer and the soldier as ideal attitudes with regard to the world. But he pictured the labourer as "a historical type" rather than a representative of the proletariat. For him the labourer adhered to the philosophy of heroism and asceticism and is therefore alien to the cult of happiness being aware that "[...] man will never be happy" and "suffering involves absolute values which we don't want to renounce" (Brzozowski 1990, 248). What joins the labourer and soldier is their ethics of heroic struggle with nature. As Brzozowski explained:

The psychology of the soldier, that is, the man who treats his life as a sentrypost, a militant and enterprising psychology, grounded in an all-pervasive sense of responsibility, is the fundamental force of the survival and 
development of culture. [...] We have to learn to see the world from an acquisitive perspective: we have to tear our own fate, our future out of it. Something of the soldier has to inhere in every Pole [Brzozowski 2001, 207].

This ethics of a "permanent state of emergency" (Rowiński 1975, 61) was an important part of Brzozowski's project for modernizing Poland which he saw as the condition for regaining independence lost in 1795 . He declared: "I want to waken the Poles from the idyll of their stateless, apolitical existence" (Brzozowski 1970b, 236).

But Brzozowski's attitude towards modern world was ambiguous. He wrote that "a deeply national and modern psyche is a requirement" (Brzozowski 2001, 433) while at the same time admitting that "[...] I am not able to tolerate many so called modern ideas and only regret that I do not have enough strength to expunge all of them from credulous Polish brains" (Brzozowski 1970b, 424).

\section{5}

So should we label Brzozowski's ideas as fascist or pre-fascist? Only to the extent that Sorel, Papini, Prezzolini and other contemporaries of Brzozowski could be labeled fascists. This means likewise that he was neither racist nor anti-semitic. Rather the opposite in fact-he was critical of the biological and racist theories of culture propounded by Gobineau, Wagner or Chamberlain (Brzozowski 1990, 395) and he sympathized with the Jews. He feared possible collectivism as "a great tragedy" (Brzozowski 1970b, 173) for which reason he became fascinated, in the very last days of his life, with John Henry Newman and English Catholicism.

One can say that it is the ambiguity and originality of Brzozowski's ideas and his ambivalent attitude towards modernity that preclude finding an adequate description for them, in particular in the Polish and Central European context. Brzozowski foresaw this: "I will be classified as an ultra-reactionary writer" [ibid., 433]. Nevertheless, labels like "reactionary" or "fascist" seem today not to be appropriate. It would be better to call Brzozowski "antimodern" in the sense in which Antoine Compagnon used the term in his excellent book about French writers of the nineteenth and twentieth centuries, who were disenchanted with modernity yet still modern, who quarreled with their contemporaries yet belonged neither to Right nor the Left (Compagnon 2005). Compagnon begins his book with a list "antimoderns" whose names begin with "B-Balzac, Beyle, Ballanche, Bloy, Barrès, Bernanos... I think Brzozowski would fit perfectly here.

Open Access This article is distributed under the terms of the Creative Commons Attribution Noncommercial License which permits any noncommercial use, distribution, and reproduction in any medium, provided the original author(s) and source are credited.

\section{References}

Adamson, W. L. (1993). Avant-garde Florence. From modernism to fascism. Cambridge, London: Harvard University Press. 
Berlin, I. (2004). Joseph de Maistre i źródła faszyzmu. In I. Berlin (Ed.), Pokrzywione drzewo człowieczeństwa. (H. Hardy, M. Pietrzak-Merta (Ed.), Trans.). Warszawa: Prószyński i S-ka.

Brzozowski, S. (1970a). In M. Sroka (Ed.), Listy. T. I. Kraków: Wydawnictwo Literackie.

Brzozowski, S. (1970b). In M. Sroka (Ed.), Listy. T. II. Kraków: Wydawnictwo Literackie.

Brzozowski, S. (1975). In M. Wyka (Ed.), Sam wśród ludzi. Wrocław: Ossolineum.

Brzozowski, S. (1990). In S. Góra \& M. Sroka (Eds.), Idee. Wstęp do filozofii dojrzatości dziejowej. Kraków: Wydawnictwo Literackie.

Brzozowski, S. (2001). In J. Bahr \& S. Góra (Eds.), Legenda Mtodej Polski. Studia o strukturze duszy kulturalnej. T. I. Kraków: Wydawnictwo Literackie.

Brzozowski, S. (2007a). In O. Ortwin (Ed.), Głosy wśród nocy. Studia nad przesileniem romantycznym kultury europejskiej. Warszawa: Wydawnictwo Krytyki Politycznej.

Brzozowski, S. (2007b). In M. Wyka \& M. Urbanowski (Eds.), Pamiętnik. Wrocław: Ossolineum.

Burek, T. (1974). Miejsce Brzozowskiego w XX-wiecznym sporze o romantyzm. In A. Walicki \& R. Zimand (Eds.), Wokót mysti Stanistawa Brzozowskiego (pp. 7-42). Kraków: Wydawnictwo Literackie.

Compagnon, A. (2005). Les Antimodernes. De Joseph de Maistre à Roland Barthes. Paris: Gallimard.

De Felice, R. (1976). Interpretacje faszyzmu. (M. de Rosset-Borejsza, Trans.). Warszawa: Czytelnik.

Fryde, L. (1966). In A. Biernacki (Ed.), Wybór pism krytycznych. Warszawa: Państwowy Instytut Wydawniczy.

Gentile, G. (2004). Qu'est-ce que le fascisme? Historie et interpretation. (P.-E. Dauzaut, Trans.). Paris: Gallimard.

Goetel, F. (2006). In M. Urbanowski (Ed.), Pisma polityczne. "Pod znakiem faszyzmu” oraz szkice rozproszone 1921-1955. Kraków: Arcana.

Herf, J. (1986). Reactionary modernism: Technology, culture and politics in Weimar and the Third Reich. Cambridge: Cambridge University Press.

Mencwel, A. (1976). Stanistaw Brzozowski. Ksztattowanie mysii krytycznej. Warszawa: Czytelnik.

Mencwel, A. (1990). Etos lewicy. Esej o narodzinach kulturalizmu polskiego. Warszawa: Państwowy Instytut Wydawniczy.

Miłosz, C. (1982). Człowiek wsród skorpionów. Studium o Stanisławie Brzozowskim. Warszawa: Państwowy Instytut Wydawniczy.

Miłosz, C. (1996). Legendy nowoczesnośí. Eseje okupacyjne. Listy-eseje Jerzego Andrzejewskiego i Czestawa Miłosza. Kraków: Wydawnictwo Literackie.

Nolte, E. (1966). Three faces of Fascism. Action Française-Italian Fascism-National Socialism. (L. Vennewitz, Trans.). New York: Holt, Rinehart and Wilson.

Pomian, K. (1974). Wartość i siła: Dwuznaczność Brzozowskiego. In A. Walicki \& R. Zimand (Eds.), Wokót mysti Stanistawa Brzozowskiego (pp. 43-98). Kraków: Wydawnictwo Literackie.

Rowiński, C. (1975). Stanistawa Brzozowskiego "Legenda Młodej Polski” na tle epoki. Wrocław: Ossolineum.

Sroka, M. (1970). Przedmowa (pp. VII-LXXX). In Brzozowski (1970a).

Stawar, A. (1957). Szkice literackie. Warszawa: Państwowy Instytut Wydawniczy.

Stępień, M. (1976). Spór o spuścizne po Stanistawie Brzozowskim w latach 1918-1939. Kraków: Wydawnictwo Literackie.

Sternhell, Z. (1986). Neither Right nor Left. Fascist Ideology in France. (D. Maisel, Trans.). Princeton: Princeton University Press.

Sternhell, Z., Sznajder, M., \& Asheri, M. (1994). The birth of fascist ideology. From cultural rebellion to political revolution. (D. Maisel, Trans.). Princeton: Princeton University Press.

Suchodolski, B. (1933). Stanistaw Brzozowski. Rozwój ideologii. Warszawa: Instytut Literacki.

Trzebiński, A. (1999). Korzenie i kwiaty myśli współczesnej (pp. 49-57). In A. Trzebiński, M. Urbanowski (Ed.), Aby podnieść róże. Szkice literackie i dramat. Warszawa: Fronda.

Walicki, A. (1977). Stanistaw Brzozowski-drogi mysii. Warszawa: Państwowy Instytut Wydawniczy.

Wasiutyński, W. (2000). De Man i Brzozowski. In A. Lubicz (Ed.), Entuzjazm. Antologia publicystyki tygodnika "Prosto z mostu" 1935-1939 (pp. 122-125). Warszawa: Fronda.

Wolin, R. (2004). The seduction of unreason. The intellectual romance with fascism from Nietzsche to postmodernism. Princeton: Princeton University Press.

Wyka, K. (1972). Filozofia czynu i pracy u Jerzego Sorela i Stanistawa Brzozowskiego. "Pamiętnik Literacki” (z. 3). 